\title{
COMMON EUROPEAN SECURITY AND DEFENCE POLICY
}

\author{
Venelin Terziev ${ }^{1}$, Svilen Stefanov ${ }^{2}$, Vanya Banabakova ${ }^{3}$ \\ ${ }^{1}$ Corresponding Member of the Russian Academy of Natural History, Moscow, Russia, Prof. \\ D.Sc. (Ec.), D.Sc. (National Security),D.Sc. (Social Activities), Ph.D., National Military University, \\ terziev@skmat.com \\ 2Prof, Ph.D., National Military University, Veliko Tarnovo, Bulgaria, sestefanov@abv.bg \\ ${ }^{3}$ Prof. Ph.D., National Military University, Veliko Tarnovo, Bulgaria, email: v.banabakova@abv.bg
}

\begin{abstract}
This paper examines the importance and specificities of the common European security and defence policy. The realization of the common European security requires the establishment of a joint European defence. The national security and defence strategies of EU member states are an expression of a concrete implementation of a pan-European policy vision in this area, refracted through the national features of each country. The common view and purpose of the different countries presuppose cooperation and joint action in the fight against international terrorism, and by virtue of the tasks they perform, intelligence agencies are called upon to play a leading role in this fight.
\end{abstract}

Keywords: General European Policy, Security, Defence.

\section{INTRODUCTION}

The situation in the world in the last several decades characterizes with dynamic transformation of international relations. There is a trend for breaking the model of national state, which is capable of existing independently only until recently, because politics, business, security and even culture are internationalizing and each one of these spheres becomes more and more dependent on external factors. After the two-pole confrontation era, disintegration of multinational states started, a trend for strengthening the economic and political positions of significant number of states and their integration unions appears. The lack of stable statehood in some states and regions, the occurrence of energy and economic crisis, world terrorism and the weapons and drugs spreading led to crises and armed conflicts arising. An important feature of modern security environment is the integration of individual states and extension of the cooperation among them, with which they objectively keep their common interests in many international security issues, including counteraction to weapons for mass destruction spreading, regional conflicts prevention and regulation, international terrorism and drug dealing fight, sharp global-scale ecological problems solving, migration processes control. 
The fast changing geopolitical situation and the necessity of managing all the threats and challenges outline clearly the actuality of the topic for establishing security on the European continent, necessity of multi-aspect cooperation, building structures in the field of security and introduction of a clause for common defence that unites the EU member states.

Object of the exposition is study of the EU national security and defence policy. Security is an important characteristic of modern society. Republic of Bulgaria is a state of centuries-long history and rich cultural traditions but also of unique strategic position in Europe, even appearing to be outside border for the European Union. The state's security and particularly, its national security is a system of views for ensuring the security of the individual, of society and of the state from exterior and interior threats in all spheres of social life. National security includes ensuring favourable conditions for the state's economic and social development, for global and regional stability preservation, protection of cultural, spiritual-moral, historical traditions.

Ensuring military safety appears to be a significant direction within the national security realization.

In many countries, including Bulgaria, the problem with the refugees and terrorism of cross-border that threaten world security intensified sharply. This preconditions the necessity of the whole international community's uniting the efforts, enhancing the effectiveness of the used forms and methods to fight that threat, the adoption of quick measures for its neutralization.

Subject of the present study is reviewing the significance and the specific characteristics of the Common European Security and Defence Policy. The common European security realization requires establishment of common European defence. The national security and defence strategies of the EU member states are expression of particular application of common European view for policy in this field in the light of the national characteristics of each one of the states. The common position and goal of the states suggest cooperation and joint activities in the fight against international terrorism, and according to the tasks they fulfill, the intelligence agencies are called to play leading role in that fight.

One of the important strategic directions of the Republic of Bulgaria's military security appears to be the effective interaction and cooperation with the participating states in NATO and the EU. National security requires effective membership in NATO and the EU, and suggests active foreign policy of enhanced responsibilities at observing the principles and norms of international law, contribution to the international peace and security, integration and mutually beneficial collaboration, joint activities, union's operations for stabilizing conflict regions around the world, contribution to the global fight against terrorism.

The set goal is specified through review of the following tasks:

Reviewing national security's military aspect;

Historical review of the idea for establishing cooperation in the field of security within the frame of the EU;

Realization of the EU's CSDP;

Participation of the Republic of Bulgaria and the other European countries in ensuring the European security;

Nowadays condition of the European defence policy - actions of regulatory, organizational and other nature.

\section{COMMON EUROPEAN SECURITY AND DEFENCE POLICY}

An important characteristic of modern security environment is the impossibility of a separate country to exist isolated from the international community and to ensure itself for itself security without relation and interaction with the other states in the region and the world (Georgiev, 2011a; Darzhaven vestnik; 2011b; Ministry of Defense, 2018a; Natsionalna programa, 2014a; Stoychev, 2015a; Strategiya, 2011c; 2017a; Tsitseron, 1983a; Uitni, 2009a; Havel, 1993a; Maslow, 1943a; Buzan, B., Wæver, De Wilde, 1998a; 2017b; 2017c; 2017d; 2017e; 2017f; 2017g, 2017h; 2017i).

The shaping and formulating of the Common security and defence policy /CSDP/ passes through several basic stages, each one based on the basic contracts in the EU and further develops and improves this policy. The Union is grounded on the principles of the rule of law state. This means it undertakes each action on the grounds of contracts that are approved voluntarily and democratically by all Union's member-states. The contracts are binding agreements between the EU member-states. They define the EU goals, the way of decision taking and the relations between the EU and its member-states.

We find the historical European Union roots in the Second World War. Immediately after it, Europeans are decided to prevent the repetition of such killing and destruction but almost immediately after the war, Europe is divided into Eastern and Western - the 40-year Cold war starts. In the beginning of that war, the West 
European states establish the Council of Europe in 1949. This is the first step towards cooperation between them. Six states want to get yet further in their cooperation. These states are Belgium, France, Germany, Italy, Luxembourg and the Netherlands. On May $9^{\text {th }}, 1950$ the French minister of foreign affairs Robert Schuman presents plan for more extensive cooperation between the mentioned West European states and on April $18^{\text {th }}, 1951$ these six states sign an agreement for joint management of their heavy industries - steel and coal. Thus, neither of them could make weapons to use against another state, as it was in the past. The agreement gained popularity as European Coal and Steel Community (ECSC) and comes into power from July $23^{\text {rd }}, 1952$.

Shortly after the establishment of the European Coal and Steel Community, France presents project for supranational military integration. Thus, on May $27^{\text {th }}, 1952$ the six ECSC member-states sign in Paris Treaty establishing the European Defence Community (EDC), which provides for establishing European army. The text of the treaty however is not ratified by the National Assembly of France, which, on August $30^{\text {th }}, 1954$ postpones the discussion for unspecified term. That's why the Treaty for establishing EDC does not come into power.

The next intensification of the European integration process, which, beside new challenge for the memberstates' sovereignty, is also one of the main great steps in the evolution of the European policy in the field of security and defence, is put by the Treaty on European Union (TEU), also called "The Maastricht Treaty". This treaty is accepted as the most significant event in the European integration history.

The big problems before and after the signing of the Maastricht Treaty are connected with adding two more pillars of integration to the European Union economic nature - foreign policy and security policy as well as cooperation in the field of internal affairs and justice. The mechanisms and achievements of the European political community are included and developed by the Maastricht Treaty along the second integration pillar common foreign policy and safety policy, and the beginning of common policy in the field of security and defence is set. It is provided that the Union's mission is defined and applied on the basis of intergovernmental method, foreign policy and security policy. The member-states are to support this policy actively and without reservations, in a spirit of loyalty and mutual solidarity. Its goals are:

- Protection of common values, main interests, the independence and integrity of the Union in compliance with the principles laid in the United Nations Charter;

- Strengthening Union's security in all aspects, encouraging international cooperation;

- Development and strengthening democracy and the principles of constitutional state as well as recognizing human rights and basic freedoms.

The legal ground for common foreign policy and security policy is also exposed in the Maastricht Treaty. After that, it is reconsidered in the Treaty of Lisbon. The Common Security and Defence Policy is an integral part of the Union's CFSP. European Union, on the ground of the CSDP, tries to give clarity about what capabilities it needs for response and managing for crisis of various nature and what capabilities it could develop independently, outside NATO, where most of the European countries belong.

On October $2^{\text {nd }}, 1997$ the Treaty of Amsterdam, which comes into power on May $1^{\text {st }}, 1999$. Its goal is to response to the necessity of adapting the institutions and the process of taking decisions. Beside that, the Treaty expresses the will of the member-states for the Union getting closer to the citizens and because of that, it contains provisions for transparency.

It also gives the scope of the common policy in the field of the foreign affairs and security. It includes all issues regarding the Union security, including the gradual forming of common defence policy, which could lead to common defence if the European Council takes such a decision. In this case, the Council recommends to member-states taking such a decision in compliance with their constitutional requirements. It is pointed that the Western European Union (WEU) is an integral part of the EU development and renders the Union access to operative possibilities that are equivalent to operative possibilities in this case. The Western European Union supports the Union for shaping the defence aspects of the common policy in the field of foreign relations and security.

The Treaty of Nice is signed on February $26^{\text {th }}, 2001$ and comes into power on February $1^{\text {st }}, 2003$. It is intended to remove the defects of the Treaty of Amsterdam, i.e. the institutional problems connected with the expansion that are not solved in 1997. It considers the Commission's composition, the weight of votes in the council and the expansion of fields, where decisions could be taken with qualified majority. The Treaty of Nice relieves the rules for applying enhanced cooperation and makes justice cooperation more effective. The European Charter of Fundamental Rights, prepared in advance by a special convention is adopted on the summit meeting in Nice by the chairpersons of Parliament, Commission and Council. This treaty does not 
introduce changes in the field of common foreign policy and security policy. However, shortly after its adoption it became clear that the Treaty of Nice is a temporary compromise and the Union's architecture has to be thoroughly reformed in order to guarantee its normal functioning after the expansion.

On December $13^{\text {th }}, 2007$ the twenty seven states or government leaders of the EU states sign the new treaty for amendment in Lisbon, which comes into power on December $1^{\text {st }}, 2009$, after being ratified by all memberstates in compliance with the relevant constitutional requirements of theirs. The treaty establishes also two new positions in the EU institutional architecture, one of them being directly connected with bringing the policy in the field of security to a new, higher level. The new positions are chairperson of the European Council and high representative on the issues of foreign affairs and security policy. Attempt for improving the European Union functioning is made by the Treaty of Lisbon. It repeals the old pillars' structure (the three founding pillars in the Union's integration) and it is passed to a new distribution of competencies between the EU and the member-states. The Common security and defence policy is already included in a section of the constituent agreements. The long-term goals are directed towards establishing common European defence.

After Treaty of Lisbon coming into power in 2009, the European Union's CSDP has not significantly changed and has great potential for development from political as well as institutional point of view.

The European Council sets number of initial goals in December 2013 for achieving progress regarding CADP. The expected results in 2014 include:

- Strategy for marine security, adopted by the General Affairs Council on June $24^{\text {th }}, 2014$;

- Recommendations regarding the support in the form of equipment;

- Report for CSDP missions and operations financing;

- Suggestions for implementation in regard to rapid reaction, including European Union combatant groups;

- Document for the possibilities, containing suggestions for rendering support to the management of the borders of Sahel/Sahara;

- Road map for development of industrial standards in the field of defence;

- EU political frame for cybernetic defence;

- Political frame for cooperation in the field of defence;

- EDA reports for effective and efficient cooperation of the member-states within the frame of the united projects for procurements;

- Review of the Athena40 mechanism.

The European Council sets as deadline for the connected reviw of progress the year 2015 in order to preserve the dynamics concerning these issues.

In order to achieve greater effectiveness in the field of security and defence the EU Parliament needs the support of national parliaments and the other European institutions for improving this important policy and for taking decisions that need qualified majority.

In the beginning of new millennium, security and defence military aspects acquire new dimension mainly as result of the political changes in the world, in Europe and on the Balkans. The decreasing of the national military potentials, the restriction of armaments and the strengthening of trust on global scale are additional preconditions for building the new security system. Main processes and trends influencing security's military aspects are the changes of role and position of the factor "military force" in foreign policy; the revolution in warfare and the difference appeared in the states' abilities in developing and introducing of new technologies; the changes in the notions about the preparation and conduction of military actions. The military power built based on mass armies meant for conduction of large-scale classic military operations is not effective for ensuring reliable nations' protection in the new circumstances. However, military power preserves its purpose as a tool for achieving political goals and interests. Alongside, in the beginning of the $21^{\text {st }}$ century, it is often supplement in solving crises together with economic, political, cultural, information and other influences and pressure. The main tools for solving the sharp political problems are the economic and cultural expansion, the international economic and political sanctions and as a last resort the threat of using force where no serious casualties would be. However, experience shows that these tools are ineffective in the fight against international terrorism.

Variety of approaches and practices for prevention, stopping and generally regulating armed conflict is 
observed at the still existing figurative verge between the two millennia, considered as transitional status of social-political life - through non-aggressive unions, blocks and coalitions or through neutrality, collective security systems, economic integration, diplomacy and law. Armed forces (national or multinational) and their decisive use are still a tool for security (personal, national, regional or global), i.e. something we cannot do without.

Alongside its problematic characteristics, globalization demonstrated one quite positive trend - it finally made pointless the necessity of conquering territories, thus excluding the reasons for global war conflict arising, and hence, the necessity of maintaining mass armies prepared for large-scale strategic operations with the participation of heavy armament and significant material and human resources.

The European Union Common security and defence policy presents a system for cooperation between the member-states on the issues of foreign policy. It is accepted by the participating states as a basic tool for preserving national interests in the times increasing global interdependence. The CSDP's goal is preservation and defending EU identity at international level.

No legal instruments (directives, regiments) are planned for the Common policy in the field of EU exterior affairs and security such as the Community deals with for implementing the other type of policies. The mechanism of acting in this field is political cooperation between the member-states, which has been gradually and pragmatically built based on political consensus.

The European Council, the EU Council (general affairs and exterior affairs), the European Commission (EC), the member-states and the special envoys are participants in the structuring and functioning of CSDP. The European Council defines European Union policy's principles and directions, including CSDP's.

\section{EU structures and formations constructing the capabilities for security and defence}

The European Council that took place in Cologne on June $3^{\text {rd }}$ and $4^{\text {th }} 1999$ marks crucial moment in the process of CSDP's building. European Union engages to enhance the effectivity of the European military forces as intelligence, transport, operative management and control as well as to improve the technological basis of the European defence industry.

At the European Council in Helsinki, December $10^{\text {th }}$ and $11^{\text {th }}, 1999$ the leading European states achieved consensus that establishing European forces for independent actions in crisis situation is the core of the European defence identity. Significant decisions that specify institutional changes within the EU frame, connected with the CSDP's forming and conduction, and materialize the suggestions for the establishment of European rapid reaction forces are taken in Helsinki. The following new and sitting bodies are established after the European Council's meeting in Helsinki:

- Policy and Security Committee - PSC, which to ensure political and strategic guidance of the EU managed operations. It consists of senior clerks of the member-states or their sitting representatives in the EU, which, in contrast to the previous practice for some of the WES states, excludes the possibility for participation of the new ambassadors' body to NATO.

- EU Military Committee - EUMC, which sits at military representatives or chiefs of staff level. Its main goal is to give recommendations for the EU political bodies and to manage the European military headquarters. The Committee acts on the principle of double subjection - to the European Union and to NATO. The head of the EU Military Committee participates in the sessions of the Policy and Security Committee and of NATO Military Committee, and the deputy supreme commander of NATO allied forces in Europe (DSACEUR) participates in the sessions of the European Union Military Committee.

- EU Military Staff - EUMS, which, although small in number, to perform all functions inherent for such a body in three cases - in peace times, in crisis arising and in EU managed operation. Actually, this staff is established as general directorate in the frame of Council of Europe's General Secretariat. It comprises military and civil experts from the member-states, subordinate to the Council's Secretariat. This is the only sitting integrated military structure of the European Union and receives assignments from the EU Military Committee. European Union's Military Secretariat conducts early warning, strategies planning and situation's assessment.

At the meeting in Nice, in December 2000, the European Council takes the decision to establish other sitting political and military structures, in order EU to be able to take its responsibilities on crises management fully. These new structures are Committee for Civilian Aspects of Crisis Management (CIVCOM), EU Operative Headquarters (OpHQ), EU Operational Centre (EU OpsCentre), European Defence Agency (EDA), and EU Institute for Security Studies (EUISS) and the EU Satellite Centre (EUSC).

A key point for fulfilling the requirements for EU command and management is the member-states taking 
engagement to ensure appropriate operative headquarters for the European Union. One of the options is to use the equipment granted by some of the five operative headquarters (OHQs) for the so called „autonomous operation” that are at the EU member-states disposal: French operative headquarters in Mont Valerien, Paris; British operative headquarters in Northwood; German operative headquarters in Potsdam; Italian operative headquarters in Rome; Greek operative headquarters in Larissa. The second option is through resorting to the NATO capabilities and the common forces and tools (under the Berlin Plus Agreement), to use the possibilities for command and management, for example the Operative Headquarters, situated in the Supreme Headquarters of the allied forces in Europe in Mons, Belgium, with the deputy supreme commander of allied forces in Europe (D-SACEUR) as operative commander.

Small main body of EU was established in the NATO headquarters in Belgium in 2005 (EU Group in SHAPE, Mons, Belgium) for improving the interaction, agreements and preparation of EU operations that use forces, tools and capabilities of NATO, under the Berlin Plus Agreement. This ensures full transparency between EU and NATO, realizing their strategic partnership in crises management.

Since January $1^{\text {st }}, 2007$, the Union has third option for command - from the EU Operative Centre (EU OpsCentre) in Brussels, ready for activating for missions and operations of limited scale (as the one of a combatant group - about 2000 servicemen). It activates by European Council resolution and achieves full operative readiness on the $20^{\text {th }}$ day of its activation for conduction of EU autonomous operations and especially in the sector, where civil-military responsibility is required, and in the operation's zone, where the national military headquarters is absent. The EU Operative Centre Headquarters comprises permanent Key Nucleus of 30 people staff, distributed in 6 departments, and its goal is achieving full integration between civil and military experts. The leading department for strategic planning includes 8 military and 7 civil experts. Planning's main goal is enhancing EU armed forces' capabilities for rapid action.

The European Union Institute for Security Studies and the European Union Satellite Centre are established on July $20^{\text {th }}$ 2001. The Institute has the statute of an independent agency that falls (then) in the second EU pillar - Common foreign policy and security policy. Its goal is to assist the establishing of a common European culture of security, to enrich the strategic debate and to encourage systematically Union's interests.

The Satellite Centre is responsible for processing and receiving information, derived mainly from the analysis of the pictures of the land observations from Space, in support of the process of taking decisions by the Union in the field of the second pillar. The Centre is considered main tool for enhancing the common foreign policy and the security policy (of CSDP, too), especially in observing crises and preventing conflicts.

The European Council in Laeken, December 2001, announces the EU readiness in the beginning of 2002 to conduct limited type of Petersberg operations depending on the available operative capabilities for each separate case. Year 2002 is a key one from the point of view of the perspectives for CSDP building. First, the European convent opening in February 2002 turns into public forum for presenting the various views for CSDP (then it is still European security and defence policy). This contributes to crystallize the positions as well as to engaging public attention in the present and future EU member-states with the needs and the necessary capabilities of European defence. Second, considering the challenge of large-scale expansions of the EU and NATO, the NATO meetings at the highest level in Prague in November and the European Council meeting in Copenhagen in December turn into significant starting points in the strategic analyses on the European security and defence future. A key break-through in the relationships NATO - European Union is achieved in December 2002 with the active mediation of Great Britain. This allows the successful conclusion of the activity of the working groups, established according to the European Council meeting in Fiera, on the four directions for ensuring direct access of EU to forces and tools of NATO („Berlin+”). The achieved compromise creates the necessary guarantees for the participation of Turkey and the rest of the allies, not members of the EU, in the ESDP procedures and mechanisms as well as creates clear conditions for the access to NATO forces and tools by states that are members of the EU but are not members of the Alliance. The paractical legal grounds for establishing formal cooperation between NATO and the European Union in the field of defence are created.

\section{Multinational formations in Europe. European Union joint forces}

The European Council in Helsinki announces the establishment of European Rapid Reaction Forces to 2003 as priority goal. They have to be with approximate strength of $50000-60000$ people, maintained by about 500 military and transport aircrafts and in case of need - by 15 naval vessels. The degree of readiness is 60 days, and the minimum term of their deployment is one year.

Forces' main body is the Eurocorps (about 50 thousand people) with headquarters in Strasbourg, where five states participate - France, Germany, Spain, Belgium and Luxembourg. Certified by NATO for participation 
in managed by the Alliance operations for peace maintenance, the Eurocorps participates with a contingent of 150 people in the Security Forces - SFOR in Bosnia and Herzegovina, and in the year 2000 it takes the rotating command of the NATO forces in Kosovo (KFOR). The latter is considered a significant step towards outlining ESDP, demonstrating Europe's readiness to take bigger responsibilities and to play more significant role in the field of security and defence.

\section{Eurocorps}

Established in 1992 as a concrete expression of political desire, which originates and develops with the development of the integration processes in Europe after the end of the Second World War, the Eurocorps includes military participation of the listed five European states. The Eurocorps's headquarters together with representatives of Austria, Greece, the Netherlands, Poland, Turkey and Great Britain, is situated in Strasbourg. However, since April 2001 the Eurocorps is rendered to NATO as NATO Rapid Deployable Corps Headquarters.

\section{Eurocorps' Headquarters}

The Corps' headquarters includes a command group, headquarters of maintaining battalion, four national support detachments and headquarters of multinational command-support brigade. This includes totally about 900 military men and about 70 people civil personnel. In addition, the national contribution to the Corps' headquarters includes completing some positions on rotating principle. Such are all general's and some other key positions in the rest of the formations.

At its establishment, three-star French general is placed at the head, while the deputy commander and the headquarters head are two-star generals from Germany and Belgium respectively. The headquarters head has two deputies - in operations and in maintenance (resources), one-star generals. The commander, deputy commander and the headquarters head should come from different states. The position rotation is conducted each two years. Besides that, there is a legal advisor, a team dealing with the information for the media, representatives of the air force and naval forces to the headquarters. During the operation, there is also a political advisor. All of them work directly in interest of the Corps' command.

In peace times, the national contribution lies in rendering military formations under the operative command of the Eurocorps, and the other allocated formations could be rendered in case of need and have longer term of preparation before their rendering.

The command and the headquarters from the corps' command, which task is to plan, prepare and conduct operations in the scope of humanitarian aid, reaction in crises to defence of the member-states and of NATO. In times of operation, the command manages the main subordinate to him formations and coordinates the actions of the land component with the air force and the naval forces.

The peacetime building of the headquarters includes about 370 people, civil and military. The Headquarters is situated in the southern part of Strasbourg in the barracks of Aubert de Vincelles.

After the Eurocorps' headquarters is restructured into headquarters of High Readiness Forces in 2002, it turns into similar to the standard headquarters and corpse level in NATO.

There is supporting battalion to the headquarters, which main task is to ensure its adequate maintenance (transport, equipment maintenance and repair, office maintenance, food supplies, accommodation, guarding, life and work conditions improvement, etc.). The peacetime strength of the battalion is about 330 people, including about 12 civilians. Its commander is changes every two years as the other rotation positions and is representative consecutively of the countries participating in the Eurocorps. The supporting battalion consists of three multinational companies in peacetime, but it could be significantly increased in crises, if necessary.

As far as the administrative and logistic provision of the participants in the headquarters is left national responsibility, four national supporting groups are established - of France, Germany, Spain and Belgium. Despite the fact they are not part of the supporting battalion, both teams work in close cooperation. Totally, all national supporting groups count about $190-200$ people.

There is a separate Multinational Command Support Brigade - MNCSBDE to the Eurocorp's headquarters. Principally, there is commanding, headquarter's and supporting company in the brigade, a signaling company for the brigade, three signaling providing companies for the subordinate to the Eurocorps, electronic warfare company, company military police, company for protection, section for geography and map support, engineer company and company for Chemical, biological, radiological and nuclear defense (CBRN defence). The brigade's subordinate teams do not constantly belong to it, but in case of need, they are ensured by the participating states for each separate case. The brigade headquarters' main body exists in peacetime and is situated together with the Eurocorps'; headquarters - approximate strength 
of about 80 people. It ensures the intercommunication and the deployment plans of the subdivisions for command and management's support. The supporting brigade commander changes on rotation principle by the states for a two-year term.

Subbordinate formations

The participating states agree to specify which formations from the different states would be intended for the Eurocorps yet in peacetimes. Such are:

- French-German brigade, situated in Mülheim, Germany;

- French contribution - chief headquarters of forces 4 (Etat-Major de Force numéro 4 - EMF4), situated in Limoges, France, equivalent of a division headquarters with one armoured brigade subordinate; one motorized infantry brigade; special supporting formations (if necessary);

- German contribution - $10^{\text {th }}$ armoured division with headquarters in Sigmaringen, Germany, includes12th armoured brigade in Amberg; $30^{\text {th }}$ echanized brigade in Ellwangen;

- Belgian contribution - land operative commanding with headquarters in Evere, Belgium, includes $1^{\text {st }}$ mechanized brigade in Leopoldsburg; $7^{\text {th }}$ mechanized brigade in Marche-en-Famenne;

- Spanish contribution - $1^{\text {st }}$ mechanized division with headquarters in Burgos, Spain, includes $10^{\text {th }}$ mechanized brigade in Cordoba; $11^{\text {th }}$ mechanized brigade in Badajos; $12^{\text {th }}$ mechanized brigade in Madrid;

- Luxembourg's contribution - intelligence company (180 people), situated in Diekirch, with strength of two intelligence platoons, anti-tank platoon and providing/supporting component, it integrates in the Belgian formations in times of operation.

Except the French-German brigade and the headquarters of the supporting the commanding multinational brigade, which are permanently under the Eurocorps operative commanding, the rest of the formations stay under national commanding in peacetimes. They become subordinate to the Eurocorps after the transfer of authority based on national decisions.

\section{Constitutive documents}

The Eurocorps forming, composing and the possibilities for its use are based on the following constitutive documents: the La Rochelle Report, the Petersburg and Rome Declarations

(The Petersberg and Rome Declarations), the Agreement with SACEUR

\section{La Rochelle Report}

La Rochelle Report of May $22^{\text {nd }}, 1992$ is a constitutive document for the establishment of the Eurocorps. It defines the Eurocorps as European multinational army corps, which does not belong to the NATO integrated military structure. The Report describes in details the mission, the subordination, the possibilities for manning the headquarters and the forces as well as their structure and organization, and also a number of financial and legal aspects. Initially, the Eurocorps is a French-German initiative, but it is supported by other states, members of the Western European Union.

\section{Petersberg and Rome Declarations}

The Western European Union's declaration from its meeting in Petersberg on June $19^{\text {th }}, 1992$ defines the WEU's role as the defence unit of the European Union, which also regards the EU agreements from Maastricht and Amsterdam. It is also provided the Eurocorps to strengthen NATO's European unit. In support of that decision the states participating in the Eurocorps accept on May $19^{\text {th }} 1993$ in Rome to put the Eurocorps at disposal of the Western European Union.

Three types of missions are provided for the Eurocorps:

- To be ready to conduct operations for rendering humanitarian aid and support of population after natural calamities or caused by people;

- To be prepared for missions for restoring peace or for protecting peace (for example, with mandate of UN or of OSCE);

- To be used also as mechanized army corps in higly intensive military operations to provide thw common defence of the Union members in compliance with Article 5 of the Washington Treaty or the WEU treaties (Brussels Treaty - WEU) and the European Union.

Agreement with SACEUR 
Separate agreement with the supreme commander of NATO armies in Europe defines the conditions, in which the Eurocorps would be used within NATO. It is signed on January $21^{\text {st }}, 1993$ on the behalf of the Eurocorps by French and German military representatives and by the supreme commander of the NATO armies in Europe. This agreement defines clearly:

- Eurocorps missions within NATO;

- The responsibilities when planning the use;

- The possible Eurocorps detailing under NATO commanding;

- The responsibilities and relationships between NATO military commanding and the Eurocorps commander in peacetimes.

The relationships between the Eurocorps and NATO are based on the following principles:

- Specificity of these multinational European operative forces, which is accepted with respect and is reported in NATO;

- The Eurocorps decides to adopt the NATO structure and procedures, and this will facilitate its quick integration in the Alliance's structures in case of engagement, binding for common mission.

- Common activity between NATO and the Eurocorps - the Eurocorps does not belong to the Alliance's integrated military structure; hence, it does not depend on any other senior military instance, but is directly subordinate to the multinational political management - the Common Committee.

Each Eurocorps engagement requires separate decision by the participating states, which are equally presented in the Common Committee by two high-standing representatives each (the Chief of Defence and the Political Director of the Ministry of Foreign Affairs). The decisions in the Common Committee are taken with consensus. The Eurocorps might be engaged for operation, conducted by an international organization, such as the UN, NATO, EU (WEU) and/or OSCE, or as a result of a common decision of the five memberstates. In case of demand on the behalf of an international organization, it has to be directed to the Common Committee, which can set the task to the Eurocorps.

Multinational peace forces in South Eastern Europe (MPFSEE)

An Agreement for establishing the Multinational peace forces in South Eastern Europe is signed on September $26^{\text {th }}, 1998$, during the South Eastern Europe's ministries of defence Third meeting by the ministries of defence of Albania, Bulgaria, Greece, Italy, Macedonia, Romania and Turkey.

MPFSEE establishment is an actual expression of the determination of the participating states to develop good neighbor's relations and constructive cooperation in the field of defence and security and is an important tool for more direct integration with the Euro Atlantic security structures, including NATO.

The Agreement regulates the establishment, deployment and the use of MPFSEE that are at brigade level. The multinational brigade "South Eastern Europe" - (SEEBRIG) is to fulfill tasks for support of peace, building peace and humanitarian operations. The use would be in operations with UN or OSCE mandate, under the management of NATO or the Western European Union.

The multinational brigade „South Eastern Europe” consists of only land elements, and the main subdivisions are to the size of battalion. They stay in their permanent bases of distribution and gather for the formation of the relevant forces for training- practice actions according to jointly elaborated curricula and in extreme cases, if there is political decision for that.

Multinational brigade common structure is commanding and headquarters; quarters and signaling company; combat subdivisions; supporting subdivisions; providing and servicing battalion.

Brigade's headquarters consists of 105 officers, sergeants, soldiers and military men. It is set in full strength only for trainings and operations. In the rest of the cases, headquarters main body functions, consisting of 34 people ( 1 brigade general, 3 colonels, 12 lieutenant colonels, 3 majors, 1 captain, 14 sergeants).

Three types of subdivisions are formed in the brigade:

- Subdivisions, completed and provided by the headquarters host (headquarters and signaling company);

- Multinational subdivisions (brigade headquarters, providing headquarters and battalion);

- National subdivisions (battalions, companies, platoons). The participation of the states according to the agreement for the Multinational brigade is: multinational headquarters; Albania - infantry company; 
Bulgaria - mechanized (infantry) battalion, headquarters company, signaling company, engineer platoon; Greece - mechanized battalion; Italy - mechanized battalion; Macedonia - mechanized company; Romania - infantry battalion, intelligence platoon; Turkey - mechanized battalion, self-propelled artillery battery, intelligence company; multinational battalion for providing transport, servicing and medical elements.

On May $2^{\text {nd }}, 2001$, Multinational brigade „South Eastern Europe” is announced before the UN for operatively ready to participate in operations.

\section{IMPLEMENTATION OF THE COMMON EUROPEAN SECURITY AND DEFENCE POLICY /CESDP AND ACHIEVED RESULTS}

The state and government leaders of the EU member-states defined the goals of CESDP with the adoption of the Declaration for enhancing the Common European Security and Defence Policy:

Building EU Crisis Management Forces to 2003 (50-60 000 people, who to be possible to be transferred to crisis areas within 60 days and with possibilities to stay in the conflict area for a not shorter than one-year term), independently or using NATO funds;

Development of the relevant commanding, managing and intelligence, logistic and other structures;

Establishing police forces with strength of 5000 thousand people to 2003, which to conduct international missions on conflicts prevention and crises management with possibilities for rendering 1000 policemen within term of 30 days;

Maintaining regular dialogue with NATO European states non-EU members (Turkey, Norway, Island, the Czech Republic, Poland and Hungary), the states in process of negotiations for EU membership as well as with Russia and Ukraine.

Enhancement of the strategic and operative capabilities of the member-states and re-structuring of their defence industry in medium-term and long-term;

Enhancing the capabilities of intelligence (structures of analysis and granting intelligence information, increasing the volume of the exchanged intelligence information, etc.). Now, the Satellite Centre in Torrejon for satellite information procession, processes mainly data from the air- and space-intelligence about the crises areas situation progress and for the execution of the international agreements in the field of disarmament, etc.

Here are the tasks the EU forces would fulfill: forcible split of fighting parties; peace supporting missions; humanitarian operations conduction; EU citizens evacuation from crisis areas, etc.

The following has been completed to now after the CESDP building:

EU managing bodies on CESDP were established - Policy and Security Committee (PSC), Military Committee (MC) and Military Headquarters (MH). PSC (established on 22.1.2001) is the main form for solving the problems of the CESDP common foreign policy and security policy. MC (established with resolution of 22.1.2001) includes the chiefs of the member-states general staffs and their military representatives and is the highest military body of the EU Council. MH begins its work officially on 11.6.2001 and fulfills tasks on early warning, situation evaluation and strategic planning for operations for crisis management, including identification of national and multinational forces and means for these operations as well as execution of the MC resolutions. MH's total strength is 7 generals, 105 other officers, 17 sergeants and 13 people secretariat.

Besides, it is decided to conduct regular meetings of the military intelligent forces of the EU states (on multipartite and bipartite basis). In EU managed operations (peace supporting, humanitarian or of EU citizens evacuating), they will exchange intelligence information also with the candidate-states that participate with their contingent in the union's forces. As of now, not all issues on the cooperation in the field of intelligence are solved. Despite that, there is a consensus on the necessity of the separate states' intelligence to be ready for elaborating strategic assessments about the situation in various areas in the world, in order to support the governments in taking decisions regarding EU operations in preparation or going on - they could be at a distance of 5-6 $000 \mathrm{~km}$ from Europe. An important intelligence task would also be the supplying of information in interest of the protection of the contingents that participate in the peace supporting operations. Quite significance within the CESDP is given to the development of the cooperation between the intelligent bureaus in the fight with the new global threats. Establishing an EU intelligence community is discussed as well as the elaboration of unified union's strategy to fight the international terrorism. Terrorism occupies on of the major places in the categorization of the risks and threats that modern security environment might generate. It is a direct threat for the security of the NATO states' citizens 
and in a broader aspect - for the international stability and prosperity. Extremist groups continue attempting to and in areas of strategic significance, and modern technologies enhance the threat and the potential terrorist attacks' impact, especially if the terrorists acquire nuclear, chemical, biological or radioactive capabilities. On the other hand, terrorist organizations decentralize their structures, diversify their way of acting and skillfully infiltrate in various modern society's structures, governmental and non-governmental, which significantly impedes their neutralization. The possibilities for the terrorists using radioactive materials, toxic substances and biological agents as well as for access to information databases and technologies increase.

EU situational centre, which is to be established, would be subdued to the Military Headquarters.

The cooperation between the national intelligence bureaus would intensify with the building of structures to the EU managing bodies for intelligence information analysis. Structural and procedure changes in the EU Situational centre are also planned, aiming improving its possibilities to analyze the information received from the member-states and for enlarging the volume of the exchanged intelligence information. EU Satellite Centre and the Institute for security studies' activity is also intensified in the interest of the CESDP.

Important place is also defined for the improvement of the coordination of the systems for mass destruction weapons protection, of the establishing of common rules for European air space and the improvement of the protection of the unified forces participating in humanitarian operations. General Affairs and Foreign Relations Council at ministries of defence level approved a report of the Political and Security Committee for development of the EU rapid reaction forces deployment procedures. Progress in the field of national and multinational headquarters commanding and control, of communication-information systems, radio-electronic fight means, the multiple rocket launchers and naval aviation is observed.

The European Council conclusions from Seville occupied an important place in the CESDP building, which specify the quality and quantity aspects of military capabilities. The Council emphasized the progress achieved in defining the optimal was of action of the mechanism for developing these capabilities and made a review of the procedures for crisis management with particular attention towards the interaction between civil and military components as well as to the national and multinational headquarters management and control improvement.

\section{PARTICIPATION OF EUROPEAN STATES IN THE PROVISION OF EUROPEAN SECURITY}

The Common European Security and Defence Policy (CESDP) development gains more and more particular dimensions in regard to the EU preparation for conduction of crisis management operations. The efforts for enhancing the military and civil capabilities for improving the activity of the managing bodies - the Political and Security Committee, the Military Committee and the Military Headquarters intensify. There is a common will for adopting mechanism for planning the development of its military potential considering the characteristics of planning within NATO. In result of developing the procedures of crisis management, the first Crisis Management Exercise - 02" (CME - 02) of the EU was successfully held (22-28.05.2002). Its goal was to work off the order of taking decisions in crisis management and to check the mechanism for holding consultations among the structures in ensuring effective political control and strategic guidance of Union's military potential. It showed improved coordination in the field of military and non-military aspects in crisis management as well as the necessity of further specifying and improving the procedures for decision taking by the EU political and military bodies and improvement of their interaction.

The member-states harmonized and confirmed the principles and mechanisms for financing the EU crisis management with military means operations, and the expenses would be subdivided to general (from the EU budget) and such that are born by each participating state. The funds from the Union's budget would be spent for common actions in the areas of the operations - transport, communications, infrastructure, administration, etc. The participating states will ensure the transport to the area of operations of their army contingents, their financial ensuring, the expenses for the national military equipment and other extra expenses. The solution for the financial ensuring of the management of crisis, however, is temporary; the work on further specifying the issues with the revenues and expenses control in each operation's budget, on specifying the financial rules in EU using of NATO's forces and means, the optimizing of the list of common expenses, the definition of the share of participation of third parties and others would continue.

The European Council attaches particular importance to the inclusion of EU non-member European states from NATO and to the membership candidate states for the implementation of the CESDP. Their readiness to participate in the Union's military potential forming is evaluated as positive. Agreements for cooperation with other states - potential partners were achieved (Russia, Ukraine, Canada, etc.) on the issue with 
management of crisis with military and non-military means, which includes mechanisms for consultation in peacetimes, in the pre-crisis period and in the times of crises.

Work on improving the interaction with NATO for avoiding duplication of efforts in some fields (in the bodies for operative planning, intelligence, strategic transport, management systems, etc.) as well as for finding compromise in the positions of Turkey and Greece on using NATO forces and means in EU managed operations, and others, will continue.

More, not only EU or NATO member-states participate in the operation's planning and conduction, but also many states, members of the former Warsaw Pact.

The CESDP strategic conception and long-term goal is to ensure the freedom and security of all its memberstates by political and military means. It confirms the values of democracy, human rights and supremacy of law and expresses the allies' obligation not only for ensuring the member-states defence but also for preserving the peace and stability on a global scale (Terziev, Petkov, Krastev, 2018b, pp.473-476; Terziev, Petkov, Krastev, 2018c, pp. 477-481; Terziev, Petkov, Krastev, 2018d, pp.487-491; Terziev, Petkov, Krastev, 2018e, pp.492-496; Terziev, Petkov, Krastev, 2018f, pp.501-504; Terziev, Petkov, Krastev, 2018g, pp.497- 500; Terziev, Petkov, Krastev, 2018h, pp.505-510; Terziev, Petkov, Krastev, 2018i, pp.482-486; Terziev, Petkov, Krastev, 2018j, pp.511-516; Terziev, Petkov, Krastev, 2018k, pp.517-521; Stefanov, Terziev, Banabakova, 2017c, pp.4-10; Stefanov, Terziev, Banabakova, 2017d, pp.31-36; Stefanov, Terziev, Banabakova, 2017e, pp.11-16; Stefanov, Terziev, Banabakova, 2017f, pp.40-49; Terziev, Madanski, Georgiev, 2017g, pp. 748-753; Terziev, Madanski, Georgiev, 2017h, pp. 743-747; Terziev, Madanski, Georgiev, 2017i; pp. 923-927; Terziev, Madanski, Georgiev, 2017j, pp. 1051-1055; Hristov, 2018I, pp. 183186; Terziev, Madanski, Kanev, 2017k, pp.1380-1393; Terziev, Nichev, 2016a, pp.101-106; Terziev, 2016b, s.84-90; Terziev, 2017l, pp. 1046-1061; Terziev, 2017m, pp. 940-947; Terziev. Stoyanov, Georgiev, 2017n, pp.7-11; Terziev, Nichev, 2017o, pp.502-507; Terziev, Stefanov, Banabakova, lliev, 2017p, pp.953-963; Terziev, Stefanov, Banabakova, lliev, 2017q, pp.741-757).

\section{CONCLUSION}

Security in modern society is a dynamic status of human and society. Republic of Bulgaria's national security is a system of views for ensuring the security of the individual, the society and the state from external and internal threats in all fields of social life. It formulates the most important directions of state policy.

In home aspect, it characterizes with the functioning of a democratic political system with stable consensus on the basic foreign political goals and priorities, with guaranteeing the lawful order and recognizing human rights and freedoms, with strengthening the market economy and ensuring sustainable development as well as with the protection of citizens' individual security.

In international aspect, the environment is recognized for the versatile impact of the processes of globalization and integration, the internationalization of the risks and challenges, asymmetric threats, instability in some regions around the world and the resulting transformation in the major international organizations (UN, NATO, EU).

For optimal use of the possibilities and effective overcoming of the challenges of this environment, the Republic of Bulgaria follows strategy, based on non-traditional, preventive and anticipating approaches and solutions, on coordinated and mutually supplementing efforts for engaging the state's political, economic, technological, information, military and civil resources. This strategy considers the integral nature of security and collective environment that guarantees it.

State's defence is directed towards building and using capabilities for preventing and counteracting of crises of military and non-military nature that threaten national security and in support of state authorities and society. The state realizes its defence through conduction of active and purposeful defence policy, with which it formulates, defines and ensures the achieving of the main goal, the missions and tasks of armed forces.

The policy is realized through effective and resulting national security strategy and effective UN, NATO and European Union membership. National security suggests active foreign policy of enhanced responsibilities, while observing the international law's principles and norms, contributing to the international peace and security, realizing integration and mutually profitable cooperation as well as also participating in collective actions within NATO along the entire scope, allies' or coalition operations for stabilization of conflict zones around the world and contributing to the global war against terrorism.

The defence policy of the Republic of Bulgaria after its acceptance in the EU is directed towards the establishment and maintenance of environment of security that is favourable for materializing the national 
interests. It is also an element of the overall security policy of the state. The defence policy is conducted in conditions of transparency and succession regarding the basic priorities and goals. It is realized in the context of the NATO collective defence system and of Bulgaria's EU membership.

State's defence is reorienting towards an approach that is based on building necessary capabilities in response to risks and threats. Republic of Bulgaria's armed forces, as bearers of a significant part of these capabilities, are in process of dynamic transformation. The main goal of defence - guaranteeing state's sovereignty, security and independence, and defence of its territorial integrity, is realized in the context of the collective defence allies' system (NATO) with complete engaging of national capabilities and resources.

Transformation's main goal and major task of the Ministry of Defence is building of modern and effective defence and armed forces system with capabilities and strength that are adequate to the national interests and to the requirements of the security dynamic environment. The main directions in this development are defined as result of the Strategic review of defence in the period 2003-2004 and are defined in the long-term vision fir development of armies and forces 2015 adopted by the 39th National Assembly.

The development of armies and forces is directed towards guaranteeing the maintenance of effective, efficient, multifunctional, module and mobile army units with capabilities for joint actions, for deploying on the state's territory or abroad, relatively independent and comprehensively ensured.

The efforts for ensuring national security are focused on achieving four basic priorities:

Transformation of armed forces for effective generating of necessary operative capabilities;

Transformation of the procedures and practices for forming and conducting the security and defence policy;

Effective NATO membership;

Integration in the European security and defence policy's system.

\section{REFERENCE LIST}

Georgiev, Hristo. (2011a). Rezyume na monografichen trud „Politika na sigurnost na Republika Balgariya v nachaloto na XX-vi vek: teoretichni i prilozhni aspekti“; izd. „Stopanstvo“ UNSS, Sofiya, 2011

(Георгиев, Христо. Резюме на монографичен труд „Политика на сигурност на Република България в началото на XX'-ви век: теоретични и приложни аспекти“; изд. „Стопанство“ УНСС, Софияя, 2011).

Darzhaven vestnik. (2011b). Ministerski savet. Postanovlenie nomer 9 ot 20.01.2011g. za priemane na Naredba za usloviyata i reda za uchastie na grazhdanski spetsialisti ot Republika Balgariya v operatsii i misii na mezhdunarodni organizatsii za upravlenie na krizi izvan teritoriyata na Republika Balgariya (Държавен вестник. Министерски съвет. Постановление номер 9 от 20.01.2011г. за приемане на Наредба за условията и реда за участие на граждански специалисти от Република България в операции и мисии на международни организации за управление на кризи извън територията на Република България).

Ministry of Defense. Collaboration. (2018a). Министерство на отбраната. Сътрудничество.

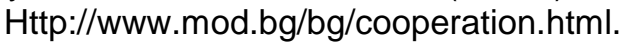

Natsionalna programa „Balgariya v NATO i v Evropeyskata otbrana 2020“ - oktomvri 2014g. (2014a). Ministerski savet (Национална програма „България в НАТО и в Европейската отбрана 2020“ октомври 2014г. Министерски съвет).

Stoychev, Stoyan. (2015a). Izsledvane sposobnostite na NATO i Evropeyskiya sayuz v otgovor i upravlenie na krizi; Sofiya, Voenna akademiya „G.S.Rakovski“; 2015 (Стойчев, Стоян. Изследване способностите на НАТО и Европейския съюз в отговор и управление на кризи; София, Военна академия „Г.С.Раковски“; 2015).

Strategiya za natsionalna sigurnost na Republika Balgariya - fevruari 2011g., (2011c). Ministerstvo na otbranata na Republika Balgariya - Tsentralno voenno okrazhie, (Стратегия за национална сигурност на Република България - февруари 2011г. Министерство на отбраната на Република България - Централно военно окръжие).

http://eurlex.europa.eu/LexUriServ/LexUriServ.do?uri=OJ:L:2005:157:SOM:BG:HTML. (2017a). 
IJASOS- International E-Journal of Advances in Social Sciences, Vol. IV, Issue 12, December 2018

Tsitseron. Mark Tuliy. (1983a). Izbrani rechi. S., Nauka i izkustvo, 1983 (Veliki oratori), Марк Тулий Цицерон. Избрани речи. С., Наука и изкуство, 1983 (Велики оратори).

Uitni, N. (2009a). Da sazhivim evropeyskata politika za sigurnost i otbrana, Evropeyski savet za vanshna politika, 2009 (Уитни, Н., Да съживим европейската политика за сигурност и отбрана, Европейски съвет за външна политика, 2009).

Havel, Vatslav. (1993a). Letni razmishleniya, izdatelstvo Prosveta, 1993 (Хавел, Вацлав; Летни размишления, издателство „Просвета”, 1993).

Maslow, A.H. (1943a). A Theory of Human Motivation, Psychological Review; 1943.

Buzan, B., Wæver, O., De Wilde, J. (1998a). Security: A New Framework for Analysis. Boulder, Colo.: Lynne Rienner Pub, 1998.

http://europa.eu/about-eu/eu-history/1945-1959/1949/index_bg.htm. (2017b).

http://europa.eu/about-eu/basic-information/symbols/europe-day/schuman-declaration/index_bg.htm. (2017c).

http://ec.europa.eu/bulgaria/abc/eu_glance/eu_timeline/index_bg.htm.(2017d).

http://www.europarl.europa.eu/sides/getDoc.do?pubRef=//EP//TEXT+IMPRESS+20070206STO02783+0+D $\mathrm{OC}+\mathrm{XML}+\mathrm{VO} / / \mathrm{BG}$. (2017e).

http://ec.europa.eu/bulgaria/abc/eu_glance/treaties_documents/treaties_bg.htm. (2017f).

http://geopolitica.eu/drugi-statii/934-evropeyskata-politika-za-sigurnost-istoriya-i-perspektivi. (2017g)

http://eur-lex.europa.eu/legal-content/BG/TXT/?uri=uriserv:ai0026. (2017h).

http://www.mod.bg/bg/doc/cooperation/EC/EC_erasmus.pdf. (2017i).

Terziev, V., Petkov, M., Krastev, D. (2018b). Operative mode for police cooperation between the member states of the European Union. // Proceedings of SOCIOINT 2018- 5th International Conference on Education, Social Sciences and Humanities, 2-4 July 2018- Dubai, U.A.E, International Organization Center of Academic Research, www.ocerints.org, pp.473-476, ISBN: 978-605-82433-3-0.

Terziev, V., Petkov, M., Krastev, D. (2018c). European arrest warrant: appearance and preferences for fulfillment. // Proceedings of SOCIOINT 2018- 5th International Conference on Education, Social Sciences and Humanities, 2-4 July 2018- Dubai, U.A.E, International Organization Center of Academic Research, www.ocerints.org, pp. 477-481, ISBN: 978-605-82433-3-0.

Terziev, V., Petkov, M., Krastev, D. (2018d). Eurojust casework on mafia-type criminal organisations. // Proceedings of SOCIOINT 2018- 5th International Conference on Education, Social Sciences and Humanities, 2-4 July 2018- Dubai, U.A.E, International Organization Center of Academic Research, www.ocerints.org, pp.487-491, ISBN: 978-605-82433-3-0.

Terziev, V., Petkov, M., Krastev, D. (2018e). Concept of joint investigation teams. // Proceedings of SOCIOINT 2018- 5th International Conference on Education, Social Sciences and Humanities, 2-4 July 2018- Dubai, U.A.E, International Organization Center of Academic Research, www.ocerints.org, pp.492-496, ISBN: 978-605-82433-3-0.

Terziev, V., Petkov, M., Krastev, D. (2018f). European arrest warrant and human rights of the accused. // Proceedings of SOCIOINT 2018- 5th International Conference on Education, Social Sciences and Humanities, 2-4 July 2018- Dubai, U.A.E, International Organization Center of Academic Research, www.ocerints.org, pp.501-504, ISBN: 978-605-82433-3-0.

Terziev, V., Petkov, M., Krastev, D. (2018g). Pumps for the action on the European Union in the scope of the European agenda on security. // Proceedings of SOCIOINT 2018-5th International Conference on Education, Social Sciences and Humanities, 2-4 July 2018- Dubai, U.A.E, International Organization Center of Academic Research, www.ocerints.org, pp.497- 500, ISBN: 978-605-82433-3-0.

Terziev, V., Petkov, M., Krastev, D. (2018h). The process of forming a criminal policy of the European Union. // Proceedings of SOCIOINT 2018- 5th International Conference on Education, Social Sciences and Humanities, 2-4 July 2018- Dubai, U.A.E, International Organization Center of Academic Research, www.ocerints.org, pp.505-510, ISBN: 978-605-82433-3-0.

Terziev, V., Petkov, M., Krastev, D. (2018i). Organization on the European Union in the sphere of penal preparation. // Proceedings of SOCIOINT 2018- 5th International Conference on Education, Social 
Sciences and Humanities, 2-4 July 2018- Dubai, U.A.E, International Organization Center of Academic Research, www.ocerints.org, pp.482-486, ISBN: 978-605-82433-3-0.

Terziev, V., Petkov, M., Krastev, D. (2018j). Sources of European Union law. // Proceedings of SOCIOINT 2018- 5th International Conference on Education, Social Sciences and Humanities, 2-4 July 2018Dubai, U.A.E, International Organization Center of Academic Research, www.ocerints.org, pp.511516, ISBN: 978-605-82433-3-0.

Terziev, V., Petkov, M., Krastev, D. (2018k). The „Source of law“ category. // Proceedings of SOCIOINT 2018- 5th International Conference on Education, Social Sciences and Humanities, 2-4 July 2018Dubai, U.A.E, International Organization Center of Academic Research, www.ocerints.org, pp.517521, ISBN: 978-605-82433-3-0.

Stefanov, S., Terziev, V., Banabakova, V. (2017c). Razbiraneto za sigurnost v postmodernoto obshtestvo. // International scientific conference „CONFSEC 2017“, 11-14 December 2017, Theoretical foundations of security, national and international security, 1, 2017, N 1(1), ISSN (PRINT) 2603-2945, ISSN (ONLINE) 2603-2953, pp.4-10 (Стефанов, С., Терзиев, В., Банабакова, В. Разбирането за сигурност в постмодерното общество. // International scientific conference „CONFSEC 2017“, 11-14 December 2017, Theoretical foundations of security, national and international security, 1, 2017, N 1(1), ISSN (PRINT) 2603-2945, ISSN (ONLINE) 2603-2953, pp.4-10).

Terziev, V., Stefanov, S., Banabakova, V. (2017d). Realiziraneto na obshtata evropeyska politika za sigurnost i otbrana v konteksta na neyniya voenen aspekt. // International scientific conference "CONFSEC 2017“, 11-14 December 2017, Theoretical foundations of security, national and international security, 1, 2017, N 1(1), ISSN (PRINT) 2603-2945, ISSN (ONLINE) 2603-2953, pp.3136 (Терзиев, В., Стефанов, С., Банабакова, В. Реализирането на общата европейска политика за сигурност и отбрана в контекста на нейния военен аспект. // International scientific conference "CONFSEC 2017“, 11-14 December 2017, Theoretical foundations of security, national and international security, 1, 2017, N 1(1), ISSN (PRINT) 2603-2945, ISSN (ONLINE) 2603-2953, pp.3136).

Terziev, V., Stefanov, S., Banabakova, V. (2017e). Nivata na sigurnost i postmodernoto obshtestvo. // International scientific conference „CONFSEC 2017“, 11-14 December 2017, Theoretical foundations of security, national and international security, 1, 2017, N 1(1), ISSN (PRINT) 2603-2945, ISSN (ONLINE) 2603-2953, pp.11-16 (Терзиев, В., Стефанов, С., Банабакова, В. Нивата на сигурност и постмодерното общество. // International scientific conference „CONFSEC 2017“, 11-14 December 2017, Theoretical foundations of security, national and international security, 1, 2017, N 1(1), ISSN (PRINT) 2603-2945, ISSN (ONLINE) 2603-2953, pp.11-16).

Terziev, V., Stefanov, S., Banabakova, V. (2017f). Obshtata evropeyska politika za sigurnost i otbrana. // International scientific conference „CONFSEC 2017“, 11-14 December 2017, Theoretical foundations of security, national and international security, 1, 2017, N 1(1), ISSN (PRINT) 2603-2945, ISSN (ONLINE) 2603-2953, pp.40-49 (Терзиев, В., Стефанов, С., Банабакова, В. Общата европейска политика за сигурност и отбрана. // International scientific conference „CONFSEC 2017“, 11-14 December 2017, Theoretical foundations of security, national and international security, 1, 2017, N 1(1), ISSN (PRINT) 2603-2945, ISSN (ONLINE) 2603-2953, pp.40-49).

Terziev, V., Madanski, V., Georgiev, M. (2017g). Offset as an economic operation and a trade practice. // Proceedings of ADVED 2017- 3rd International Conference on Advances in Education and Social Sciences 9-11 October 2017- Istanbul, Turkey. International Organization Center of Academic Research, www.ocerint.org, 2017, pp. 748-753, ISBN: 978-605-82433-0-9.

Terziev, V., Madanski, V., Georgiev, M. (2017h). Offset implementation impact on technology transfer in Bulgaria. // Proceedings of ADVED 2017- 3rd International Conference on Advances in Education and Social Sciences 9-11 October 2017- Istanbul, Turkey .International Organization Center of Academic Research, www.ocerint.org, 2017, pp. 743-747, ISBN: 978-605-82433-0-9.

Terziev, V., Madanski, V., Georgiev, M. (2017i). Offset implementation impact on technology transfer in Bulgaria. // IJAEDU- International E-Journal of Advances in Education, International Organization Center of Academic Research, www.ocerint.org, 3, 2017, N 9, pp. 923-927, e-ISSN: 2411-18.

Terziev, V., Madanski, V., Georgiev, M. (2017j). Offset as an economic operation and a trade practice. // IJAEDU- International E-Journal of Advances in Education, International Organization Center of Academic Research, www.ocerint.org, 3, 2017, N 9, pp. 1051-1055, e-ISSN: 2411-18. 
IJASOS- International E-Journal of Advances in Social Sciences, Vol. IV, Issue 12, December 2018

Hristov, Neno. (2018I). NATO Resilience, Deter and Professional Military Education. Proceedings of INTCESS 2018- 5th International Conference on Education and Social Sciences 5-7 February 2018Istanbul, Turkey, pp. 183-186.

Terziev, V., Madanski, V. Kanev, D. (2017k). Directions for improvement of the military-educational system and its contribution for strengthening national security and the defence of the country. // Sport, Education and Society, Taylor \& Francis, 22, 2017, N 8(2), Source Normalized Impact per Paper (SNIP): 1.459 SCImago Journal Rank (SJR): 1.005 Impact factor: 1.269 Ranking: 60/230 (Education \& Educational Research), 20/44 (Hospitality, Leisure, Sport and Tourism), 51/82 (Sport Sciences), Print ISSN: 1357-3322 Online ISSN: 1470-1243, pp.1380-1393.

Terziev, V., Nichev, N. (2016a). Икономически характеристики на офсетните сделки с отбранителни продукти (Economic characteristics of offset transactions with defense products). // Scientific journal „Economics and Finance“, Problems of development modern science: Theory and practice Collection of scienfic articles, 2016, ISBN 978-617-7214-33-4, pp.101-106.

Terziev, Venelin. (2016b). Human resource management systems in security and defense: social policies for social activities. // XXXII Mezhdunarodnaya nauchno-prakticheskaya konferentsiya, Evraziyskiy soyuz uchenayh (ESU), Ezhemesyachnayy nauchnayy zhurnal № 12 (33)/ 2016 Chasty 1, Moskva 30.12.2016g., 2016, ISSN 2411-6467, s.84-90 (Terziev, Venelin. Human resource management systems in security and defense: social policies for social activities. // XXXII Международная научнопрактическая конфреренция, Евразийский союз ученых (ЕСУ), Ежемесячный научный журнал № 12 (33)/ 2016 Часть 1, Москва 30.12.2016г., 2016, ISSN 2411-6467, с.84-90).

Terziev, Venelin. (2017l). Human resource management system in security and defense: social policies for socialactivities. Oxford Economic papers, 69, 2017, N 4(2), pp. 1046-1061, ISSN 0030-7653. Source Normalized Impact per Paper (SNIP): 1.096 SCImago Journal Rank (SJR): 0.928 Impact factor: 0.734 5-Yr impact factor: 1.265.

Terziev, Venelin. (2017m). Streamlining management solutions for economic, effective and efficient spending of resources for security and defense. // Oxford Journal of Legal studies, 37, 2017, 4 (2), pp. 940-947, ISSN 0143-6503, Source Normalized Impact per Paper (SNIP): 1.006 SCImago Journal Rank (SJR): 0.332 Impact factor: 0.887 5-Yr impact factor: 0.718 .

Terziev, V. Stoyanov, E., Georgiev, M. (2017n). The balanced scorecard model as atool for improvement of the national defense system management (Моделът балансирана карта за оценка като инструмент за усъвършенстване на управлението в работата на националната система за отбрана и сигурност). // Research: tendencies and prospects: Collection of scientific articles. - Editorial Arane, S.A. de C.V., Mexico City, Mexico, 2017, ISBN 978-0-9942661-5-6, pp.7-11.

Terziev, V., Nichev, N. (20170). Main features of the offsets in defense trade, // IJASOS- International EJournal of Advances in Social Sciences, 3, 2017, N 8, e-ISSN: 2411-183X, pp.502-507.

Terziev, V., Stefanov, S., Banabakova, V., Iliev, I. (2017p). Implementation of the common European security and defense policy in the context of its military aspect. // Fifteenth International Scientific Conference: Knowledge in practice, Bansko, Bulgaria, International Journal of Knowledge and Learning, Institute of Knowledge Management- Skopje, 20, 2017, N2, pp.953-963, ISSN 1857-923X for e - version, ISSN 2545-4439 for printed version.

Terziev, V., Stefanov, S., Banabakova, V., Iliev, I. (2017q). Common European security and defense policy. // Fifteenth International Scientific Conference: Knowledge in practice, Bansko, Bulgaria. International Journal of Knowledge and Learning, Institute of Knowledge Management- Skopje, 20, 2017, N2, pp.741-757, ISSN 1857-923X for e - version, ISSN 2545-4439 for printed version. 